Diabetologia $9,422-425(1973)$

(C) by Springer-Verlag 1973

\title{
Treatment of Isolated Fat Cells with Trypsin Inhibits the Effects of Insulin on Incorporation of Leucine into Protein
}

\author{
T. Sakai, ** V.R. Lavis and R. H. Williams \\ Division of Endocrinology, Department of Medicine, University of Washington School of Medicine, Seattle, Washington \\ 98195, USA
}

Received: April 16, 1973, and in revised form: June 12, 1973

\begin{abstract}
Summary. Incorporation of $0.1 \mathrm{~m} \cdot \mathbf{M}^{3} \mathrm{H}$-leucine into protein by isolated fat cells, with pyruvate as the only extracellular carbohydrate, was stimulated by : a) insulin, $0.1-4 \mathrm{ng} / \mathrm{ml}$, or b) a mixture of 19 amino acids, $0.05-$ $5 \mathrm{mM}$. Treatment of fat cells with trypsin, under conditions known to reduce binding of insulin by their plasma membranes, abolished stimulation of incorporation by the hormone but not by the amino acid mixture. These
\end{abstract}

results imply that the actions of insulin on incorporation of amino acids into protein are initiated by interaction with plasma membranes.

Key words: Isolated fat cells, insulin, trypsin treatment, plasma membranes, amino acid incorporation, amino acid mixture.
Receptors on fat cell plasma membranes are thought to mediate the effects of insulin on glucose metabolism and lipolysis $[1-4]$. Insulin also stimulates incorporation of amino acids into protein. We attempted to find out whether this hormonal effect, which does not depend on the aforementioned metabolic changes $[5,6]$, also begins at plasma membranes.

\section{Materials and Methods}

Twice-crystallized trypsin was obtained from $\mathrm{Nu}$ tritional Biochemicals, crystalline soybean trypsin inhibitor from Worthington, and cycloheximide and puromycin dihydrochloride from Sigma. Single component porcine insulin [7] and other reagents [8] were as previously described.

During storage of ${ }^{3} \mathrm{H}$-leucine ${ }^{1}$ (New England. Nuclear), there appeared a radiochemical impurity which would bind to the albumin of incubation media, thereby producing spurious "incorporation" in the absence of cells. Therefore, at intervals of two to three months the ${ }^{3} \mathrm{H}$-leucine was repurified by paper chromatography (solvent, $n$-butanol/acetic acid/water, $4 / 1 / 1, \nabla / v / v)$. This procedure reduced the impurity to $0.1 \%$ of the total radioactivity, corresponding to $10 \%$ of the true basal incorporation by fat cells.

Isolated rat fat cells were prepared and counted as previously described [8]. Incubation flasks contained $3 \times 10^{5}$ to $4 \times 10^{5}$ fat cells, $5 \times 10^{4}$ to $1 \times 10^{5} \mathrm{cpm}$ ${ }^{3} \mathrm{H}$-leucine, 50 nanomoles of L-leucine and additions, as described in the text, in albumin-bicarbonate medium [8], total volume $0.5 \mathrm{ml}$. Incubations were stopped

* A preliminary report of this work was presented on June 22, 1972, at the IVth International Congress of Endocrinology, Washington, D.C. (abstract No. 423).

* Present address: Nagoya City University, School of Medicine, Department of Biochemistry, Mizuho-ku, Nagoya, Japan.

1 Abbreviation: ${ }^{3} \mathrm{H}$-leucine, L-leucine $-4,5-{ }^{3} \mathrm{H}$. by addition of $3 \mathrm{ml}$ Dole's mixture [9], with vigorous mixing. Protein precipitates were collected by centrifugation, washed once with $5 \%$ trichloroacetic acid containing $0.01 \mathrm{M}$ nonradioactive leucine, heated to $90^{\circ}$ for $30 \mathrm{~min}$, cooled, and trapped on glass-fibre discs (GF/A, Whatman). After further washing with $5 \%$ trichloroacetic acid, the discs were transferred to scintillation vials, and $1 \mathrm{ml}$ "NCS" (Amersham/Searle) or "Protosol" (New England Nuclear) was added. The precipitates were dissolved at $\mathbf{5 5 ^ { \circ }}$, and counted at $25 \%$ efficiency in a toluene-based scintillator. ${ }^{2}$

Treatment of fat cells with trypsin, $1 \mathrm{mg} / \mathrm{ml}$ for $10-15$ min, was by the method of Kono[3]. Control cells were carried through the same manipulations, with the omission of trypsin and inhibitor. Trypsintreated cells had no more insulin-degrading activity than control cells, as determined by immunoassay of the media before and after incubation (data not shown).

\section{Results}

Incorporation of ${ }^{3} \mathrm{H}$-leucine into the product was essentially abolished by inhibitors of protein synthesis (Table 1). When no substrate was added to the incubations, insulin did not significantly stimulate incorporation (data not shown). The substrate routinely employed was $0.5 \mathrm{mM}$ pyruvate, which allowed a maximal response to insulin (Table 2 ). The half-maximal dose of insulin was about $0.4 \mathrm{ng} / \mathrm{ml}$ (Fig. 1).

Increasing concentrations of a mixture of all the natural amino acids except leucine, progressively augmented both basal and insulin-stimulated incorporation (Table 3). At a total concentration of $5 \mathrm{mM}$, the mixture appeared to supplant the effects of insulin. No single

2 Composition: 2,5-diphenyloxazole (PPO), $4 \mathrm{~g} / \mathrm{L}$; 1,4-bis-2-(5-phenyloxazolyl)-benenze (POPOP), $50 \mathrm{mg} / \mathrm{L}$ in toluene. 
Table 1. Effects of inhibitors of protein synthesis on incorporation of leucine.

\begin{tabular}{|c|c|c|}
\hline $\begin{array}{l}\text { Date of } \\
\text { Experiment }\end{array}$ & Additions & $\begin{array}{l}\text { Incorporation } \\
\text { nanomoles } / 10^{6} \\
\text { cells } / 1 \mathrm{~h}\end{array}$ \\
\hline $2 / 25 / 72$ & $\begin{array}{l}\text { None } \\
\text { Cycloheximide: } 0.01 \mathrm{mM} \\
0.1 \mathrm{mM}\end{array}$ & $\begin{array}{l}2.74(2.59-2.93) \\
0.26(0.25-0.26) \\
0.16(0.14-0.19)\end{array}$ \\
\hline $2 / 28 / 72$ & $\begin{array}{l}\text { None } \\
\text { Puromycin: }\end{array}$ & $\begin{array}{l}2.29(2.15-2.39) \\
0.07(0.06-0.08)\end{array}$ \\
\hline
\end{tabular}

Fat cells were incubated for $1 \mathrm{~h}$ with $0.5 \mathrm{mM}$ pyruvate and additions as noted in the table. Incorporation of ${ }^{3} \mathrm{H}$-leucine into protein is shown as the mean value from one experiment, with the range of triplicate incubations in parentheses.

sugar or amino acid could reproduce this phenomenon (data not shown). After fat cells were treated for 10 to $15 \mathrm{~min}$ with trypsin, $1 \mathrm{mg} / \mathrm{ml}$, their incorporation of ${ }^{3} \mathrm{H}$-leucine was stimulated fully by the amino acid mixture, but their responsiveness to a supramaximal concentration of insulin was diminished (Table 4).

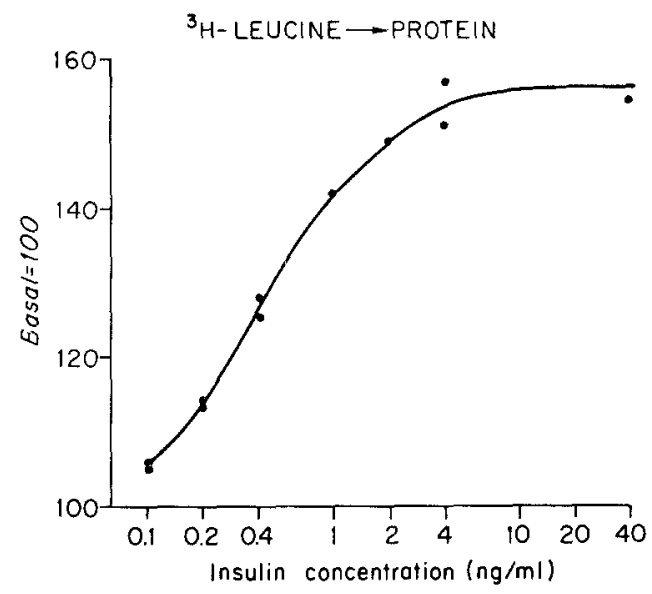

Fig. 1. Dose-response curve for insulin. Incubations were for $1 \mathrm{~h}$, with $0.5 \mathrm{mM}$ pyruvate added. Each point is the mean of quadruplicate incubations in one experiment, expressed relative to a value of 100 for incorporation without insulin. Mean absolute values for incorporation without insulin; 1.97 (experiment 1) and 2.49 (experiment 2) nanomoles $/ 10^{6} \mathrm{cells} / 1 \mathrm{~h}$

Table 2. Glucose or pyruvate as energy sources for leucine incorporation

\begin{tabular}{llll}
\hline $\begin{array}{l}\text { Additions to } \\
\text { Incubation medium }\end{array}$ & \multicolumn{2}{l}{$\begin{array}{l}\text { Incorporation } \\
\text { nanomoles } / 10^{6} \text { cells } / \mathrm{h}\end{array}$} & $\begin{array}{l}\text { Mean change } \\
\text { produced by } \\
\text { insulin }\end{array}$ \\
\cline { 2 - 4 } No insulin & Insulin, $40 \mathrm{ng} / \mathrm{ml}$ & $+35 \%$ \\
\hline Glucose, $5 \mathrm{mM}(15)$ & $2.22 \pm 0.08$ & $3.01 \pm 0.10$ & $+38 \%$ \\
Pyruvate, 0.5 $\mathrm{mM}(45)$ & $2.46 \pm 0.06$ & $3.38 \pm 0.10$ & $+38 \%$ \\
Pyruvate, $5 \mathrm{mM}(3)$ & $2.88 \pm 0.56$ & $4.00 \pm 0.81$ & +30 \\
\hline
\end{tabular}

Fat cells were incubated for $1 \mathrm{~h}$, with additions as indicated in the table. In corporation of ${ }^{3} \mathrm{H}$-leucine into protein is expressed as mean \pm S.E. for the number of sets of triplicate incubations shown in parentheses.

Table 3. Effects of amino acid mixture on incorporation of leucine

\begin{tabular}{|c|c|c|c|}
\hline \multirow{2}{*}{$\begin{array}{l}\text { Additions to } \\
\text { Incubation medium. }\end{array}$} & \multicolumn{2}{|c|}{$\begin{array}{l}\text { Incorporation } \\
\text { nanomoles } / 10^{6} \text { cells } / 1 \mathrm{~h} \\
\end{array}$} & \multirow{2}{*}{$\begin{array}{l}\text { Mean change } \\
\text { produced by } \\
\text { insulin }\end{array}$} \\
\hline & No insulin & Insulin, $40 \mathrm{ng} / \mathrm{ml}$ & \\
\hline $\begin{array}{l}\text { Pyruvate, } 0.5 \mathrm{mM} \\
\text { Pyruvate, } 0.5 \mathrm{mM} \\
+ \text { Amino acid mixture }\end{array}$ & $3.27(3.15-3.36)$ & $4.31(4.21-4.40)$ & $+32 \%$ \\
\hline $0.05 \mathrm{mM}$ & $3.51(3.49-3.53)$ & $4.61(4.52-4.66)$ & $+31 \%$ \\
\hline $0.5 \mathrm{mM}$ & $4.07(4.02-4.11)$ & $4.93(4.74-5.04)$ & $+21 \%$ \\
\hline $5 \mathrm{mM}$ & $5.24(5.17-5.37)$ & $5.55(5.42-5.58)$ & $+6 \%$ \\
\hline
\end{tabular}

Fat cells were incubated for $1 \mathrm{~h}$, with additions as indicated in the table. The amino acid mixture consisted of equimolar amounts of $\mathrm{L}$-alanine, $\mathrm{L}$-arginine, $\mathrm{L}$ asparagine, L-aspartic acid, L-cysteine, L-glutamic acid, L-glutamine, L-glycine, L-histidine, L-isoleucine, L-lysine, L-methionine, L-phenylalanine, L-proline, $\mathrm{L}$-serine, L-threonine, L-tryptophan, L-tyrosine, and L-valine, dissolved in incubation medium. The sum of the final concentrations of all the amino acids is indicated in the table. Incorporation of ${ }^{3} \mathrm{H}$-leucine into protein is expressed as the mean value from one experiment, with the range of triplicate incubations in parentheses.

\section{Discussion}

The abolition of incorporation by inhibitors of protein synthesis suggests that the product we measured was not formed by nonspecific binding of the label. The dose-response relationship and magnitude of stim- ulation by insulin are in agreement with a previous report [5].

Exogenous metabolizable substrate was required for stimulation of incorporation by insulin. Previous investigators, who reported otherwise $[5,10]$, had in fact supplemented their incubation media with amino 
acid mixtures. We have not explored in detail the characteristics which permit a substrate to support the effect of insulin. The provision of all the natural amino acids circumvented some rate-limiting step(s) on which insulin acts, presumably by virtue of properties of the constituents other than their ability to serve as fuel, since comparable amounts of carbohydrates or single amino acids did not supplant the effects of insulin.

\section{References}

1. Rodbell, M.: Introduction. The fat cell in mid-term: its past and future. In: Adipose tissue. Regulation and metabolic functions, pp. 1-4; Jeanrenaud, B., Hepp, D., (eds.). New York: Academic Press 1970

2. Fain, J.N., Loken, S.C.: Response of trypsin-treated brown and white fat cells to hormones. Preferential inhibition of insulin action. J. biol. Chem. 244, 3500$3506(1969)$

Table 4. Responses of trypsin-treated fat cells

\begin{tabular}{|c|c|c|c|c|c|}
\hline & \multirow[b]{2}{*}{$\begin{array}{l}\text { Basal } \\
\text { incorporation * } \\
\text { a. }\end{array}$} & \multicolumn{2}{|c|}{ Stimulation $* *$ by } & \multirow[b]{2}{*}{$\begin{array}{l}\text { "p" } \\
\text { bvs. a }\end{array}$} & \multirow[b]{2}{*}{ c vs. a } \\
\hline & & $\begin{array}{l}\text { Insulin, } \\
40 \mathrm{ng} / \mathrm{ml} \\
\text { b. }\end{array}$ & $\begin{array}{l}\text { Amino acid } \\
\text { mixture, } 5 \mathrm{mM} \\
\text { c. }\end{array}$ & & \\
\hline 1. Control & $2.42 \frac{ \pm}{(8)} 0.34$ & $+36.8 \underset{(8)}{(8)} 4.9 \%$ & $+36.0 \underset{(3)}{ \pm} 2.3 \%$ & $<0.001$ & $<0.01$ \\
\hline $\begin{array}{l}\text { 2. Trypsin- } \\
\text { treated }\end{array}$ & $\frac{2.14 \pm}{(8)} 0.33$ & $+14.2 \underset{(8)}{ \pm} 3.1 \%$ & $+28.7 \underset{(3)}{3(3.7 \%}$ & $<0.01$ & $<0.02$ \\
\hline "p" 1 vs. 2 & N.S. & $<0.01$ & N.S. & & \\
\hline
\end{tabular}

* nanomoles $/ 10^{6}$ cells $/ 1 \mathrm{~h}$

** per cent change from basal incorporation

Fat cells were treated with trypsin as described in the text. They were then incubated with $0.1 \mathrm{mM}{ }^{3} \mathrm{H}$-leucine and $0.5 \mathrm{mM}$ pyruvate. Results are expressed as mean $\perp$ S.E., for the number of sets of triplicate incubations shown in parentheses. Values for " $p$ " were calculated by the two-tailed " $t$ " test, based on paired comparisons [21].

Treatment of fat cells with trypsin is thought to modify the affinity [11] and/or capacity $[12,13]$ of membrane binding sites for insulin. The ability of trypsin-treated fat cells to respond to the amino acid mixture indicates that they retained the capacity to augment incorporation of leucine. We therefore infer that the receptors for the action of insulin on leucine incorporation are on cell surfaces and are accessible to trypsin.

Until now, the hypothesis that interaction of insulin with plasma membranes suffices to initiate all the effects of the hormone $[14,15]$ has been supported only by measurements of glucose metabolism and lipolysis $[2,3,12]$. Stimulation of amino acid incorporation, which may be mediated by an improved ability of fat cells to maintain intracellular amino acid concentrations $[16,17]$, does not depend on changes in glucose metabolism or lipolysis $[5,6]$. Therefore, our results extend the support for the above hypothesis. Further confirmation will now require measurements of "intracellular" effects of insulin such as improvement in ribosomal function $[18,19]$ or induction of enzyme synthesis [20].

Acknowledgements. Mrs. Barbara Zimmer and Mrs. Nora Scofield rendered expert technical assistance. Dr. Ralph Stoll and Mrs. Jeanette Teague kindly provided single component insulin. This research was supported by research grants AM-02456, AM-05020, and AM-15263 from the U.S. Public Health Service (NIAMDD) and a Research Grant from the American Diabetes Association awarded to $\mathrm{V}$. Lavis. During a portion of this investigation, V. Lavis was a trainee under National Institutes of Health grant AM-1000.
3. Kono, T.: Destruction and restoration of the insulin effector system of isolated fat cells. J. biol. Chem. 244, $5777-5784(1969)$

4. Cuatrecasas, P.: Interaction of insulin with the cell membrane: the primary action of insulin. Proc. nat. Acad. Sci. (Wash.) 63, 450-457 (1969)

5. Minemura, T., Lacy, W.W., Crofford, O.B.: Regulation of the transport and metabolism of amino acids in isolated fat cells. Effect of insulin and a possible role for adenosine 3', 5'-monophosphate. J. biol. Chem. 245, 3872-3881 (1970)

6. Jarett, L., Steiner, A.L., Smith, R.M., Kipnis, D.M. : The involvement of cyclic AMP in the hormonal regulation of protein synthesis in rat adipocytes. Endocrinology 90, 1277-1284 (1972)

7. Stoll, R.W., Ensinck, J.W., Williams, R.H.: Immunologic and biologic activities of the heterogeneous components of insulin. Diabetes 18, 392-396 (1969)

8. Lavis, V.R., Williams, R.H.: Studies of the insulinlike actions of thiols upon isolated fat cells. J. biol. Chem. 245, 23-31 (1970)

9. Dole, V.P.: A relation between non-esterified fatty acids in plasma and the metabolism of glucose. J. clin. Invest. 35, 150-154 (1956)

10. Miller, L.V., Beigelman, P.M.: Stimulation by insulin of protein synthesis in isolated fat cells. Proc. Soc. exp. Biol. (N.Y.) 122, 73-75 (1966)

11. Cuatrecasas, P.: Perturbation of the insulin receptor of isolated fat cells with proteolytic enzymes. Direct measurement of insulin-receptor interactions. J. biol. Chem. 246, 6522-6531 (1971)

12. El-Allawy, R.M.M., Gliemann, J.: Trypsin treatment of adipocytes: Effect on sensitivity to insulin. Biochim. biophys. Acta (Amst.) 273, 97-109 (1972)

13. Kono, T., Barham, F.W.: The relationship between the insulin-binding capacity of fat cells and the cellular response to insulin. J. biol. Chem. 246, 6210-6216 (1971) 
14. Levine, R.: Action of insulin: An attempt at a summary. Diabetes 21, (Suppl. 2), 454-456 (1972)

15. Cuatrecasas, P.: The insulin receptor. Diabetes 21, (Suppl. 2), 396-402 (1972)

16. Touabi, M., Jeanrenaud, B.: Alpha-aminoisobutyric acid uptake in isolated mouse fat cells. Biochim. biophys. Acta (Amst.) 173, 128-140 (1969)

17. Vassalli, J.D., Jeanrenaud, B.: Lipolysis and alphaaminoisobutyrio acid uptake in isolated fat cells. Biochim. biophys. Acta (Amst.) 202, 477-485 (1970)

18. Wool, I.G.: Insulin and amino acid transport in muscle. In: Protein and polypeptide hormones. Margoulies, M. (ed.) Proceedings of International Symposium, Liege, May 19-25, 1968, pp. 285-295. Amsterdarn: Excerpta Medica 1969
19. Pilkis, S.J., Korner, A.: Effect of diabetes and insulin treatment on protein synthetic activity of rat liver ribosomes. Biochim. biophys. Acta (Amst.) 247, 597$608(1971)$

20. Hansen, R.J., Pilkis, S.J., Krahl, M.E.: Effect of insulin on the synthesis in vitro of hexokinase in rat epididymal adipose tissue. Endocrinology 86, 57-65 (1970)

21. Goldstein, A.: Biostatistics, an introductory text, p. 55. New York: The Macmillan Company 1964

Dr. Victor R. Lavis

Department of Medicine $R G-20$

University of Washington

School of Medicine

Seattle, Washington 98195 , U.S.A. 